\title{
A Comparative Analysis of Chinese Cultural Values and Western Cultural Values from the Perspective of "Power Distance"
}

\author{
Sha Zhu \\ Huaiyin Institute of Technology \\ Huai'an, China 223001
}

\begin{abstract}
Value can determine people's different behaviors and thoughts to a great extent. The contrasting cultural values in different countries can also explain the different ways people follow in their life. However, value is abstract and difficult to illustrate, so, power distance dimension, put forward by the famous social psychologist Geert Hofstede, can be used to help understanding the different values in different cultures. Therefore, this thesis mainly makes a comparative analysis on the cultural values of China and Western countries from three perspectives such as family, workplace and school. After these examples chosen in these aspects, power distance theory can be used to explain the distinction. Further, related strategies will be discussed in the end, with the aim of improving the intercultural competence in the global communication.
\end{abstract}

Keywords-cultural values; power distance; comparative analysis

\section{INTRODUCTION}

With the development of globalization, international communication is becoming more and more frequent, a great number of Chinese English learners experienced culture shock in the new cultural environment. To alleviate cultural shock, one important way is to have a better understanding of the root difference between Chinese culture and western culture, which is, the diversities in ideas, beliefs and values, which are underlying but essential and even can determine other differences. However, values are not so easy to be explained. Thereby, the "power distance" cultural dimension by Geert Hofsted will be applied to aid to illustrate different values in different cultures, with the aim of helping people avoid trouble to strengthen cross-cultural communication and realize mutual understanding.

\section{LITERATURE REVIEW}

\section{A. Value}

According to Cultures and Organizations: Software of the Mind, Geert Hofstede describes that, "Values are broad tendencies to prefer certain states of affairs over others." (Hofstede, 2010)Values are the deepest part of culture, dominating people's belief, attitude and behavior (Wang, 2014). Values have great impact on people's thought and they can guide people's activities. Values are the standards of a group and specific persons to assess everyone's behaviors. Values are sanctified by usage and they can make persons distinct from other groups in making decisions. If people can be familiar with local cultural values, they will communicate more easily.

\section{B. Power Distance}

Cultural dimensions theory was firstly put forward by Geert Hofstede, a Dutch social psychologist, accounting for the reasons why values differ from countries to countries. In his book Cultures and Organizations: Software of the Mind, Geert Hofstede points out that "Power distance can therefore be defined as the extent to which the less powerful members of institutions and organizations within a country expect and accept that power is distributed unequally. Institutions are the basic elements of society, such as the family, the school, and the community; organizations are the places where people work." (Hofstede, 2010) In view of $\mathrm{Hu}$ Zhongli (2014), power distance is a criterion which can measure the degree of power inequality acceptance.

Hofstede (2010) also considers that power distance differences within countries are related to social class, education level, and occupation. "The occupations with the lowest status and education level showed the highest power distance index (shorted for PDI) values, and those with the highest status and education level produced the lowest PDI values." ( Hofstede, 2010). Power distance index in working class family is higher than that in middle class family. China has high PDI with 80, America with 40, Canada with 39 and Britain with 35. Small power distance culture has lower PDI. Hofstede found countries like Austria, New Zealand, the United States, Demark, and Finland have small power distance culture. Large power distance culture gets higher PDI. Hofstede found that countries, such as China, Malaysia, South Korea, Mexico, Indonesia, Pakistan, India, and Japan are large power distance countries.

From Hofstede (2010) western countries enjoy low power distance culture. Western countries are pursuing more freedom and equality. In contrast, China is paying more attention to order and tolerance. Both Fang Jing (2010) and $\mathrm{Hu}$ Zhongli (2014) all agree with Hofstede that western countries are low power distance cultures. China, as a classic Asian country, is a high power distance society. 


\section{A COMPARATIVE ANALYSIS OF CHINESE CULTURAL VALUES AND WESTERN CULTURAL VALUES FROM THE PERSPECTIVE OF "POWER DistANCE"}

This part will analyze with a large number of examples to compare differences between Chinese cultural values and western cultural values from the following four common aspects: family, workplace, and school.

\section{A. The Perspective of Family}

Everyone has families, so the differences in values reflected in family dimension will be discussed in the first place. The movie of The Joy Luck Club will be taken as related examples. Four pairs of mothers and daughters in the movie represent different cultural values. Mothers represent Chinese culture and daughters represent America culture because mothers were born and grew up in China, while their daughters were born in America and also live there all their life.

Suyuan Woo, the mother of June contributed almost herself to her daughter's education. She cleaned up the room for a piano teacher with no pay so that she could get more time to practice piano. However, June failed in piano performance, and she didn't want to play the piano any more, which as a result led to a conflict between them. June cried out 'I'm not your slave. This isn't China. You can't make me. You want me to be someone I'm not! I'll never be the kind of daughter that you want me to be!" Mother shouted "There be two kinds of daughter: obedient or follow own mind. Only one kind of daughter could live in this house: obedient kind." In traditional Chinese family, children are seldom at open defiance with parents. So Suyuan Woo was unexpected to face daughter's resistance, she saw her as an immoral girl. In her eyes there are only two kinds of daughters, obedient ones and disobedient ones and only obedient daughter could be her daughter. Nevertheless, June was not a traditional Chinese girl, she was influenced by American cultural values, and she wanted to be treated equally. She wanted to pursue her own life, not at the mercy of her parents. June had adopted American core spirit. In the end, she did not play the piano until her mother died. Obviously, the mother represents large power distance values while the daughter symbolizes small power distance cultural values. In large power distance, it is necessary for children to be obedient to parents. Objecting to parents is immoral and will be critical. So this mother never thought her daughter should object to her. June received small power distance cultural values; she thought she would be treated equally and she had her own feeling. But power distance between them makes it difficult to understand with each other. In large power distance societies, parents require their children to be obedient and they will take care of their children until they grow up, have step generation. Further, parents are always warmhearted to help their children take care of step generation; even they want to have a relaxation. Chinese parents contribute too much to children, so in Chinese traditional culture, obedience is reasonable. On the other hand, when they grow up children must take care of their parents, especially when parents are old. Therefore, parents are sovereign to children. Parents lay stress on docility. In small power distance culture, American parents show more democracy to their children. And parents are also willing to share ideas with their children and accept advice from them. But as a traditional Chinese mother, June's mother didn't treat her in a democratic way, so June felt unsatisfied with her mother.

Waverly invited her American boyfriend Rich to visit her home. When Waverly's mother, Lindo presented her best dish, she devaluate her dish, "This dish is not salty enough, not flavor. It's too bad to eat, but please." Chinese guests all complimented the dish. However, Rich didn't know Lindo's real meaning and added sauce to the dish, "You know, Lindo...all this needs is a little soy sauce.", which made Lindo very embarrassed. In traditional Chinese custom, people prefer to be humble to convey a sense of pride. In large power distance cultures, people are accustomed to devaluating themselves to show politeness. Besides, as traditional Chinese people, they will keep an attitude with tolerance to the elder member of a family. Even if parents cook dishes not so well, children will eat dishes happily to show respect to parents. It is also impolite to comment on elder's behaviors in public in large power distance cultures. Furthermore Chinese younger generations are not allowed to call elder generations' name straightly. Compared with Chinese custom, people in small power distance cultures will tend to criticize things straightly. In Small power distance cultures, children will be treated equally and their ideas will be accepted by parents. Children will give their advice to parents directly or criticize their parents without hesitation. And they are not as obedient as Chinese children. Americans tend to call parents' name directly because parents are children's friends. As an American, Rich didn't know Chinese traditional custom; he only understood the literal meaning of Lindo's words and criticized Lindo's cooking. Rich just did what he wanted to do. He didn't notice that Lindo was a traditional Chinese mother. Besides, he called Lindo's name directly, which really made Lindo shocked. He didn't know Chinese large power distance culture.

Rose Hsu Jordan lived happily before she got married with her husband Ted. She was too dependent on her husband after married to lose herself. She behaved as a traditional Chinese woman, obedient to her husband. Everything should be decided by her husband. She received traditional Chinese value to eat humble pie. She never thought to violate against her husband even Ted wanted to break her marriage. She only stayed in the room until Ted packed luggage. Her mother advised her to be independent, finally she saved her marriage. Rose in her marriage showed large power distance cultural values. She only followed her husband and cared about husband, did housework all day. She lost her status; she didn't speak out her views and she wasn't aware of it. But Ted was in small power distance culture, he needed to hear about her wives' opinion, but all the decisions were made by him in the end. He felt uncomfortable about his servant wife. His marriage was unhappy any more. He wanted to leave Rose because of their power distance. But Rose conquered difficulty and achieved her marriage. In large power distance culture, traditional Chinese women are in center of husband. Wives depend on 
their husbands, because husbands are the pillar of the family, making money for the family. So women in large power distance cultures may not be treated as equal as husband. In small power distance cultures, women have higher social status. They are treated relative equally; wives have more freedom in showing themselves. Wives think they are masters, not servants in the family. Rose treated her husband with large power distance value, so Ted felt uncomfortable.

Besides, because of power distance, how to call the parents is different. In Chinese family, age and status determine the oldest man to be the most powerful one, who is the nuclear of the family and he can call other's name directly, but the younger generation mustn't call his name straight. What's more, titles of mother's relatives and father's relatives are quite different, showing a degree of distance. Chinese call father's father and mother's father differently and the title of mother's father presents a sense of alienation. In western family, both relatives of mother and relatives of father are titled equally, children call mother's father and father's father both grandfather, without distinction.

In the famous sitcom Growing Pains, the Seavers presented us a typical American family, which left a deep impression on traditional Chinese family and people could feel small power distance cultural values in America. The first son of the Seavers, Mike was put in jail because of driving without license. Before he went out his father, Jason had made his swore to be responsible for his behavior himself. His father was quite angry to see him but still found his son to have a talk. Father didn't blame Mike directly but inquired the reason why Mike drove. Mike answered that his friend was drunk and he wanted to show off in front of girls. Jason thought Mike not trust him so he didn't ask father to drive for them. Then Mike apologized for his behavior and father forgave him. In this sitcom, father Jason always mentioned friendship and trust between son and him. Besides, he executed the power as a father. Properly speaking, father is a model of children with a friendly way. This case shows small power distance in American family. Children are treated equally as parents' friends and they are respected and encouraged to live, think independently.

Generally speaking, Chinese family shows large power distance cultural values. It is necessary for Chinese to be obedient to their parents and respect the elders of the family. And parents will make children do something their children disliked. Large power distance in Chinese family decides people in the same generation have different titles because of blood relationship. But after opening and reform, power distance between Chinese parents and children is much shorter than before; children are treated equally by parents gradually.

Western family shows small power distance cultural values. Parents are children's friends and guiders. Children and parents are respected with each other equally and democratically. Both relatives of mother and father are same. People in the family can express ideas freely even grandchildren will communicate with grandfather equally.

\section{B. The Perspective of Workplace}

To a certain degree, workplace is another important situation for all the people. To go further, employer is a role like parents, and employees like children. A case is as follows. Someday, a Chinese employee was required to submit a report to his employer. This Chinese was a freshman in New York but he worked hard. The employer, American required this Chinese man to finish this important report on schedule, and asked the employee how much time he needed. However, the Chinese man didn't know when to submit and he couldn't decide how long he should take. His employer thought he was the decision-maker of his own time schedule. Therefore, the Chinese answered that he needed 20 days to finish. His employer just gave him 15 days to finish this important report. Actually this report would take 30 days as routine. As a result, the Chinese didn't complete report within 15 days though he had worked round the clock. He needed another day to finish. His employer was very angry and didn't receive his report because they agreed on 15 days. The Chinese employee resigned the next day, which shocked his employer (Wang, 2014). In this case, Chinese employee symbolized Chinese cultural values. Chinese culture is large power distance culture while American culture is small power distance power distance culture. In large power distance cultures employee must follow the order of employer, that's to say, everything should be completed in accordance with the requirement of the employer, and they always cannot have different opinions with their employer. So the Chinese employee in this case was also accustomed to waiting for the order from the employer. But Americans always work independently. And the American employer in the case thought his employee had right to decide when to hand in the report. Though the Chinese had completed his work within 16 days, much smaller than regular work, he didn't submit as required. Chinese employee couldn't understand American's small power distance culture and he could only resign. Small power distance culture makes employees free in decision-making and if the requirement of employer is improper the subordinates can give suggestions. Chinese employees take it for granted that employers have power and they are reasonable to be that. Employees are obedient to higher class employer. And employers enjoy their power as well. So the Chinese man in this case couldn't understand his employer to let himself make decisions by himself.

Besides, the conflicts on cultural values are universal in joint ventures. For example, Lenovo purchases IBM, employees from American feel confused about Chinese management, they feel not at ease about Lenovo. In Lenovo, organization is classified with different levels. Lenovo stresses development of a whole company. Compared with Lenovo, IBM attaches more importance to individual development of every employee, its values is "respect for individual". And, their communication approaches are different. Few employees in Lenovo can give advice to leaders. In Lenovo few representatives are selected to communicate with employers face to face. Even when they have the opportunity to express themselves, they dare not speak too much. They convey suggestions very cautiously, because they are afraid of making mistakes or putting their 
foot in their mouths, alienating leaders. It is common and safe in any situation in China. More often than not, information flows from employers rather than from employees. However, it is the opposite way round in IBM. They encourage every employee to express his ideas and adopt selectively. IBM is willing to know opinions of employees and improve accordingly. Although Lenovo always carries out "equality, trust, appreciation, and kinship," no one can really put forward his opinion freely without hesitation. Chinese employees often consider their leaders' orders correct, while Americans consider their roles are equal. Maybe centrally-authorized leadership is common in Chinese enterprises. IBM prefers to take a democratic approach to manage. So, enterprises from different cultural backgrounds need to learn more about cultural differences so that dealing with multinational enterprises can be effective (Fu, 2008).

Lenovo is a large power distance company while IBM is a small power distance company. Employees in Lenovo respect their leaders, and they seldom give suggestion to leaders. Large power distance culture doesn't allow people to speak out ideas freely. They are too cautious to show themselves. Small power distance culture allows people to show their opinions without hesitation. Employees in IBM are respected and their objections are valued. In small power distance countries, employees and employers are relatively equal in class. Their differences only exit in division of labor.

Similar to in the family, Chinese elder leaders won more respect and people often call them with title and surname such as Manager Li. People also always call elder surname plus Old, call younger little plus surname to show their age distance. When social status has conflict to age, higher status can have power to call elder's name. But in the western nations, people all call other Mr., Mrs. or Miss. in front of the surname.

\section{The Perspective of School}

Power distance between students and teachers in China is larger than western countries. Weather in ancient China or nowadays, teacher has high social status. There is an ancient saying in China: Whoever taught you a day will be your father for life.

American teachers are relaxed in class and a little casual, for instance, an American teacher teaching in Chinese college prefers to talk with students about interesting things of foreign countries. He not only focuses on textbooks and paperwork but also put theory into practice. He always likes to make students sit together around himself and he sits on the desk chatting with each student. What's more, seats in the class are not fixed; students can sit everywhere they hoped or they can move the seats to the suitable place. Sometimes he would like to bring a guitar to class and teaches students his favorite country music again and again. The atmosphere is very relaxed and students can enjoy the class. Teaching context is not restricted to textbook; any interesting video can be used as teaching context. He always plays some interesting talk show without captions and asks several questions about the video or let students dub a film.
He uses "I think", "I suggest" instead of "you need", "you have to" to give advice. The American teacher also likes to creative new stories and encourages students to continue them by turns. Teacher pays more attention to students' regular performance not just the final exam; he lays stress on oral expression and actual reactive potency.

American is a small power distance country; its culture shows equality and freedom. Teachers in small power distance cultures will treat students as equal as teachers. The courses are in center of students, making them interested in studying, improving their creative spiritual and discovering their own learning methods. Students are encouraged to express themselves. Therefore, Chinese students abroad will also feel like a fish out of water at first. Chinese students accustomed to spoon-feeding can't keep pace with American students. Because American students always discuss in the class or even some students argue against professor. American professors always require students to take part in the discussion, raise questions and share own ideas. Students' frequency of class participation will influence impression in professor. Chinese students will feel shocked. In large power distance cultures students must observe the power of professor and dare not object to professors' even other students' opinions. Some students don't adapt to expressing their opinions in public.

In traditional classes, students must raise hands then they can answer teacher's question or ask questions in class in a serious order. Children are too dependent on teachers to think individually. They seldom doubt whether what teachers said are correct or incorrect. Teachers are in the leading position of the whole course, teaching process is under the control of teachers, students having no right to speak freely in class. Traditionally, teachers always leave a strict, stiff impression on students. They are often serious in speech and humor.

In recent years Chinese educational model is changing towards students-central model. Teachers are no longer authority; students are the master of learning. Power distance is getting smaller than before. Teachers not only teach knowledge, but also mental guider, turning to be equal friends. Students are encouraged to take part in class, say more opinions without hesitation, review lesson in an individual way, then they will not be afraid of expressing themselves or being blamed. Teachers return class to students and improve their expression ability, also strengthen equal sense.

\section{CONCLUSION}

This paper mainly discusses comparative analysis of Chinese cultural values and western cultural values based on the Power Distance Theory from four perspectives of family, workplace, school and government. Based on this theory, differences between Chinese values and western values are obvious. In the family, parents in large power distance cultures want children to be obedient and care for parents when they are old. Parents in small power distance cultures treat children relatively democratic and show respect to their children. In the workplace, Chinese employees dare not give 
suggestions to employers and they only wait for the order from employers. American employers encourage employees to share their own ideas. In the school, traditional class is still popular in large power distance countries. Students in China are shy to express their opinions to teachers. However, atmosphere in American class is active and free, because teachers often discuss with students.

But nowadays China has experienced many great changes. Distance is not as large as before. But people still need to pay attention to the specific features of large power distance cultures. When entering another culture, no matter it is a small or large power distance society, the new comers are supposed to bear the following saying in mind, that is, when in Rome, do as the Romans do. In other words, try to get to familiar the new culture and gradually adapt to the ways often applied in that culture.

\section{REFERENCES}

[1] Fu Xingjia. Power Distance in Chinese and American Enterprises A comparative Study Based on Lenovo and IBM[D]. Master thesis, Renmin University of China. 2008.

[2] Fu Ying. Power Distance in the Chinese and American Family - A Comparative Study Based on Parent-Child Relation[D]. Master thesis, Xi'an Polytechnic University. 2012

[3] Hofstede, Geert. Cultures and Organizations: Software of The Mind (Revised and Expanded 3rd Edition)[M]. New York: McGraw-Hill, 2010 .

[4] Jiao Mimi. On the Differences of Family Concept between Chinese and Western Cultures in Terms of Cultural Dimensions - A Case Study of Ang Lee's Movies The Family Trilogy[D]. Master thesis, Hefei University of Technology. 2012.

[5] Song Heping. Pragmatic Differences of the Politeness Principle and Power Distance Dimension in Chinese and American Culture[D]. Master thesis, East China University of Science and Technology. 2002.

[6] Yong Jianqiong. On the cultural differences in the power distance and individualism/Collectivism of human resource management[D]. Master thesis, Southwestern University of Finance and Economics. 2008.

[7] Zhang Wei. A Comparative Research on Parenting between China and the United States from the Perspective of Cultural Dimensions[D]. Master thesis, Southwest Petroleum University, 2014. 